\title{
Bureaucratic Executivism and the Erosion of Collegiality in Nigeria's Nascent Federal Universities: Insights from a Vintage Case
}

\author{
AL CHUKWUMA OKOLI* \& SUNDAY ORINYA*1
}

${ }^{*}$ Department of Political Science, Faculty of Social Sciences, Federal University of Lafia, Nigeria

\begin{abstract}
This paper examines the erosion of collegiality in Nigeria's nascent federal universities against the backdrop of the rising bureaucratic-executivist tendencies in such institutions. On a vintage case of one of such universities, the paper observes that there has been a sustained systematic subversion of collegial ethos through gradual bureaucratic centralism and excesses. By means of a qualitative analysis that relies on a synthesis of primary and secondary data, the paper highlights aspects of these bureaucratic-excecutivist tendencies and underscores their implications for internal institutional autonomy and academic freedom. We find that the trend is tantamount to emasculation and usurpation of the collegial integrity of faculty and, in effect, negates the principles of academic sovereignty and freedom. To reverse this trend, the paper makes a case for an institutional reform aimed at devolving strategically university governance in a manner that restores the functional autonomy of the faculty alongside the sovereignty of the academia.
\end{abstract}

\section{Keywords}

academic freedom, bureaucracy, bureaucratic executivism, collegiality/collegialism, institutional autonomy, university governance

DOI: https://doi.org/10.24132/cejop_2020_1

How to cite

Okoli, A.C. and Orinya, S. 2020. "Bureaucratic Executivism and the Erosion of Collegiality in Nigeria's Nascent Federal Universities: Insights from a Vintage Case." Central European Journal of Politics 6 (2): 1-22. DOI: https://doi.org/10.24132/cejop_2020_1

${ }^{1}$ Address: Al Chukwuma Okoli, PhD, Senior Lecturer, Department of Political Science, Faculty of Social Sciences, Federal University of Lafia, PMB 146, Maraba Akunza, Obi Road, Lafia, Nasarawa State, Nigeria. Email: chukwuma.okoli@socsci.fulafia.edu.ng. Sunday Orinya, Lecturer, Department of Political Science, Faculty of Social Sciences, Federal University of Lafia, PMB 146, Maraba Akunza, Obi Road, Lafia, Nasarawa State, Nigeria. E-mail: orinya_sunday@socsci.fulafia.edu.ng 


\section{Introduction}

The university is a traditional organization principally dedicated to the production and reproduction of knowledge, as well as interrogation and transformation of conventional episteme. It is composed of tenured and non-tenured academics, researchers and parabureaucrats who work in clusters of faculties and establishments loosely structured into an organic and self-regulating system (Baldridge 1971; Russel 1993; Nybom 2008). The academic corps is the core of the university system. In most instances, especially in Africa, this constituent of the university system devolves way from the Senate (central academic board) to the faculty and departmental boards, with functional extensions to allied academic units and associated academic staff platforms (Jowi 2018). These structures play pivotal role in the governance of a university.

Originally, the university system was run on the basis of academic leadership, based on the principle of collegiality. In that regard, leadership and responsibility were laterally decentralized on the basis of expertise in scholarship (Babalola 2014), while academic departments and faculties played decisive roles in the governance of the system. Although the post-World War welfarist/ interventionist states promoted an overly bureaucratized university system, this emphasis on bureaucracy is today being widely challenged "by a normative preference for collegiality" (Sigh 2005: 11): what could be referred to as the 'collegialism redux' after Pollitt (2014: 1). Paradoxically, most contemporary universities are still enmeshed in the unwieldy bureaucratic tradition and tendencies. As Babalola (2014: 9) succinctly puts it, "Nigerian universities are weighed down by the bureaucratic demands of political correctness, reporting and regulation that stifle productivity and capacity to innovate". This happens in the wider context of restrictive institutional relations whereby 'Exaggerated concerns with 'efficiency' and 'excellence' lead to increased regulation and surveillance of scholarly output, rendering academic freedom vulnerable to formulaic measures of performance that may be insensitive to the work of African academics" (Mama 2006: 1).

So, rather than deepening the culture of collegiality, most Nigerian universities have taken to increased bureaucratization and executivism, with the attendant consequences on institutional autonomy in general and academic freedom in particular. Consequently, just like in most African universities, the "prerequisites for the existence of a healthy and vibrant academia, not to mention academic freedom, are not in existence..." (Mama 2006: 15). It is against the backdrop of the above context and observations that the paper seeks to investigate how the bureaucratic-executivist tendencies in Nigerian universities affect the culture of collegiality as well as the prospects of proper university autonomy and academic liberty in that regard.

Extant scholarship on the subject of university governance/ autonomy in Nigeria has generally privileged the external dimensions of university autonomy (Jonathan 2006; Ekundayo \& Adedokun 2009; Arikewuyo 2013; Olorunsora 2018). In that regard, 
emphasis is often laid on the relationship between the university administration and the wider society, including the government and industry, as well as donor agencies (Engwall 2007; Mukoro 2013). While such perspectives are important, they have, nonetheless, failed to factor into their analyses the equally important internal dimensions of the subject. The paper looks at some critical aspects of the rising bureaucratic-executivist varsity tradition in Nigeria by considering the often dialectical relationship between the bureaucratized university management and the faculty, with particular reference to a case drawn from the nascent generation of federal universities (see Table 1).

In the main, the paper seeks to proffer answers to a set of pertinent questions, to wit: How does bureaucracy affect the culture of collegiality in Nigeria's nascent public universities? How does undue bureaucratization undermine academic freedom at the faculty? How could the bureaucratic-executivist tendencies be moderated in the in the interest of institutional autonomy and academic freedom? In tandem, the paper posits that the prevailing bureaucratic-executivist ambience of the university tends to erode and emasculate the culture of collegiality, thereby vitiating proper institutional autonomy and academic freedom.

The remainder of the paper is thematically structured into seven sections based on the underlying objective. What comes next is a highlight of the basic terms that form the conceptual thrust of the-paper. This is followed by an exploration of literature on issues in university governance and autonomy. Next is the theoretical framework, designed to proffer an analytical anchor to the discourse. This is in turn followed by an attempt to situate the context, scope and methodology of the underlying study. Thereafter is an analysis of facets of bureaucratic tendencies in the focal university, next to which is the examination of some implications of that trend for institutional autonomy and academic freedom. The last is conclusion alongside recommendations.

\section{Conceptual frame of reference}

Six key terms constitute the conceptual thrust of this paper, namely academic freedom, bureaucracy, collegiality, institutional autonomy, university, and university governance. This section presents the contextual-cum-operational meanings of these concepts in Table 1. 
Table 1. Operational Definitions of Basic Concepts

\begin{tabular}{|c|c|}
\hline Term & Operational Definition \\
\hline $\begin{array}{l}\text { Academic } \\
\text { freedom }\end{array}$ & $\begin{array}{l}\text { The right of an academic to operate within the statutory and professional ambits } \\
\text { without unlawful epistemic, pedagogic, ideological or structural restrictions. It } \\
\text { encompasses security of tenure as well as the right of the faculty to determine the } \\
\text { structure, content and administration of the curriculum. Technically, the idea of } \\
\text { academic freedom is embodied in the concept of institutional autonomy in its broadest } \\
\text { sense. Crucial aspects of academic freedom include freedom of/ from (cf. Mama 2006; } \\
\text { Arikewuyo 2013): } \\
\text { - teaching and discussion; } \\
\text { - research and publishing; } \\
\text { - institutional or political censorship; } \\
\text { - professional association. }\end{array}$ \\
\hline $\begin{array}{l}\text { Bureaucracy/ } \\
\text { Bureaucratic } \\
\text { executivism }\end{array}$ & $\begin{array}{l}\text { Bureaucracy is used restrictively in this context to designate a system of large-scale } \\
\text { organizational leadership/ management characterized by hierarchical orientation, } \\
\text { command and control, corporate centralism, etc. (see McLean and McMillan 2003). } \\
\text { Bureaucratic centralism in the context of this study refers to the excessive } \\
\text { bureaucratization of the university system in such manner that stifles the faculty and } \\
\text { negates internal institutional autonomy as well as academic freedom. Bureaucratic } \\
\text { excecutivism relates to the chief-executive model of university management, } \\
\text { characterized by undue and abusive incursions of bureaucracy within the academic } \\
\text { portfolio in the faculty. }\end{array}$ \\
\hline $\begin{array}{l}\text { Collegiality/ } \\
\text { Collegialism }\end{array}$ & $\begin{array}{l}\text { Collegialism/Collegiality implies that the university faculty and academic committees } \\
\text { or platforms allied to it constitute critical centres of decision-making (cf. Rabah 2015). } \\
\text { Governance in this system is run on the basis of collegial and peer academic leadership. } \\
\text { Features of collegiality in the context of university governance include: } \\
\text { - shared leadership responsibility and governance; } \\
\text { - fluid and non-hierarchical management structure and line of reporting (lateral } \\
\text { devolution); }\end{array}$ \\
\hline $\begin{array}{l}\text { Institutional } \\
\text { autonomy }\end{array}$ & $\begin{array}{l}\text { Institutional autonomy refers to the relationship between the university and its } \\
\text { diverse stakeholders with reference to operational (in)dependence (cf. Martini 2016). } \\
\text { External autonomy refers to the relationship between the university and the wider } \\
\text { society while internal autonomy has to do with the relationship between the university } \\
\text { authority and the faculty. The later refers also to academic sovereignty in a more } \\
\text { nuanced sense. }\end{array}$ \\
\hline $\begin{array}{l}\text { University/ } \\
\text { Collegial } \\
\text { university }\end{array}$ & $\begin{array}{l}\text { Institution of higher learning specializing in research as well as teaching of } \\
\text { undergraduate and post-graduate programmes across various academic disciplines. } \\
\text { The notion of the university here encompasses its organizational structure and } \\
\text { community, including the students, teachers, and administrative and other staff of a } \\
\text { university. The conception of university in this paper is biased towards the collegial } \\
\text { model (cf. Baldridge 1971; see also Table 2, column 3). }\end{array}$ \\
\hline
\end{tabular}




\begin{tabular}{|l|l|}
\hline $\begin{array}{l}\text { University } \\
\text { governance }\end{array}$ & $\begin{array}{l}\text { Control and coordination of the various stakeholders and activities of the university } \\
\text { towards the realization of its purpose. The crux of university governance is to optimize } \\
\text { institutional performance by applying the available resources to efficient use (cf. } \\
\text { Osisioma 2012; Ogunbadeniyi and Uhumwuangho 2014). }\end{array}$ \\
\hline
\end{tabular}

Source: Authors' contextual definitions, edified by insights from the various sources cited in-text.

\section{Perspectives on university governance and autonomy: a literature review}

University governance refers to the relationship between the internal and external stakeholders of the university system, aimed at realizing both the strategic and civic ends of the system (Engwall 2007). It is a multi-stakeholders' process that involves the staff and students' bodies, statutory boards at the departmental and faculty level, the University Senate and Council, the University Management, as well as the various governmental and non-governmental oversight structures (Mignot-Gerard 2003).

The crux of university governance is to strategically balance the imperative for institutional autonomy and academic liberty (freedom) with the demand for public accountability (Jonathan 2006; Babalola 2014). The notion of institutional autonomy is at best problematic. According to Nybom (2008: 137), "Autonomy, in this regard, is certainly no synonym for independence; it is rather a case of widened scope of decision-making under certain important constraints, with less local power but more responsibility". Hence, institutional autonomy is a matter of leveraging the stake-holding capacity of the university vis-à-vis the external stakeholders (especially government); or that of the faculty in relation to the university administration.

Academic freedom (liberty), on the other hand, "refers to the actual working conditions of individual faculty members" (Nybom 2008:137), the essence of which is that the faculty member is a free career entity in an organizational context where he also holds a veritable stake in a collegial decision-making processes (Russell 1993; Babalola 2014). Collegial decision-making is based on consensus-seeking through long discussions and peer-consultations among the academic rank and file - a self-regulating community capable of guiding itself with little or no external hierarchical interference (Mignot-Gerard 2003).

While the collegial model emphasizes "collaborative leadership" (Mooney, Burns and Chadwick 2012: 143), whereby "faculty members become an integral part of the leadership process" (Sigh 2005: 11), the bureaucratic model favours a vertical-cumhierarchical centralization of powers in a manner that negates academic freedom and as well internal institutional autonomy (Babalola 2014). In effect, contemporary scholarship on university governance is fraught with a raging polemic as regards how and where to strike a balance between the extremes of institutional bureaucracy and collegial democracy (Sigh 2005). 
These are two dimensions to the university autonomy: external and internal. External autonomy is concerned with the operational liberty which the university management enjoys from its proprietors and funders while internal autonomy refers to the degree of freedom at the disposal of academic members of the university both as career entities and stakeholders of the system (Jowi 2018). Whereas much has been written in respect of the external dimensions of university autonomy from a variety of perspectives (Ordorika 2003; Okorosaye-Orubite, Paulley and Abraham 2012; Mukoro 2013), only a little is known concerning the internal aspects of the same processes in respect of the Nigerian context. The paper, among other things, is an attempt to address this apparent epistemic gap by considering the bureaucracy-collegiality dialectics vis-àvis its implications for institutional autonomy as well as academic integrity and sovereignty.

In order to address the afore-mentioned epistemic problematique creditably, it is apposite to situate the discourse within the framework of the 'managerialism vs. collegialism' polemics. Managerialism presupposes, among other things, the tendency to corporatize higher education administration (Deem 2000; Leshie-Hughes 2013). It "involves the exercise of power by leaders and top-management figures" (Marini and Reale n.d: 6), geared principally towards re-orientating the institution on the path of corporate entrepreneurism and executivism. On the other hand, collegialism refers to the underlying 'philosophy' implicit in the culture of collegiality as it applies to the organizational context of higher institution. It is characterised by three core elements, namely "a process of shared decision-making by a collegial group in relation to academic matters; mutual support in upholding the academic integrity of members of the group; and conservation of a realm of special knowledge and practice" (Harvey 2016: 2).

The managerial-collegial debate refers to the paradigmatic contestations between the cultures of collegiality and bureaucratic executivism in the administration of institutions of higher learning, especially the university. The tension is one of virtual antagonism. As Marini and Reale (n.d: 6), puts it, "the more a university is managerially led, the less it will be collegial, because the increasingly top-down structure of decisionmaking and the strengthening of accountability will detract from the individuality and the bottom-up voice of the peers". However, contemporary thinking on the subject matter tends to see a measurable level mutual coexistence between the two traditions. This perspective is captured in the revisionist notions of new-managerialism and newcollegialism (Deem 2000; Harvey 2016).

Generally, four traditions/ regimes of university governance are identifiable in the literature. These are statism, managerialism/executivism, commercialism and collegialism (see Table 2). Statism is a situation where the state wields a firm control of the university. In such a system, the government is deeply involved in the affairs of the university both at the level of funding and general administration (cf. Murphy 2008). Universities under this regime generally lack significant measure of operational 
autonomy. The tenets of institutional autonomy and academic freedom have no place in such a system as the universities are run as appendages of the education department of the state.

Managerialism/executivism refers to the tradition whereby the universities operate with limited autonomy under strict supervision and oversight of the state agencies. Here, institutions may exercise minimal discretion on some local matters but the government wields an overriding stake in the entire governance processes. There is much emphasis on costs recovery; hence the running of the university is modeled after the corporate sector traditions (Aspromourgos 2012). Here too, academic freedom is sacrificed at the altar of bureaucratic centralism and correctness (Babalola 2014). On the other hand, commercialism represents an outright orientation towards marketization, vocationalization and commodification. In this regard, universities are run not only with the intent to cover / recover costs but also with the purpose of making and maximizing profit. This model fits nicely into the abiding traditions of most privately owned universities in Africa, whether they are religious or 'corporate'. Here, there is much emphasis on entrepreneurialism and the penchant for institutional and personnel credentialism is widespread.

Collegialism is a tradition that devolves administrative process from the top management to the faculty where tenured academia holds sway in governing the university (Ogbogu 2013). In this system, there is an appreciable degree of functional autonomy and academic freedom as both the government and the university management accord the faculty her pride of place in university governance. Contemporary neo-liberal incursions into the global university sector have incidentally rendered this tradition more or less endangered and contested (cf. Bricks 2013). Nonetheless, elements of this tradition subsist in varying degrees in established universities. Suffice it to note that the transformation of African universities from the colonial to developmental model has led to sustained bureaucratic-executivist ascendancy. Similarly, the advent of the corporatized multivarsity model has all the more entrenched bureaucratic consolidation in African universities. In the face of these institutional changes, collegial culture has nearly become otiose and the best of what is left of it represents a mere ideal. This collegial debacle has been aptly situated thus (Weinberg and Graham-Smith 2012: 68):

As a mark of capitalist ascendancy, the university as corporate has, it would seem, lost its soul and its autonomy. The focus on collegiality invokes the communitarian and independent spirit which has for centuries been the foundation of university ideals, but which is presently undermined by managerialism and its profit-driven motives. A crass utilitarianism appropriates and 'brands' academic values to retain pseudo-prestige, while impoverishing the sense of vocation without which collegiality is rendered an anachronism. 
Table 2. Three Conceptual Regime-Models of University Governance in Africa

\begin{tabular}{|l|l|l|}
\hline Regime & Orientation & Illustrative Example(s) \\
\hline Statism & $\begin{array}{l}\text { No institutional autonomy; abusive political } \\
\text { interference / politicization; lack of academic } \\
\text { freedom (intellectual sovereignty, secured } \\
\text { tenure, and collegial / academic leadership) }\end{array}$ & Cameroon \\
\hline $\begin{array}{l}\text { Managerialism / } \\
\text { executivism }\end{array}$ & $\begin{array}{l}\text { Bureaucratization / corporatization; cost } \\
\text { recovery; clericalization; compromised } \\
\text { institutional autonomy and academic freedom }\end{array}$ & Nigeria \\
\hline Collegialialism & $\begin{array}{l}\text { Primacy of the faculty; functional institutional } \\
\text { autonomy; academic freedom; lateral devolution }\end{array}$ & $\begin{array}{l}\text { Non-existent anywhere in its } \\
\text { pure form }\end{array}$ \\
\hline
\end{tabular}

Source: Authors' original compilation.

The instances (working examples) given in Table 2 are neither exhaustive nor representative. They are merely illustrative and are designed to stimulate thinking in respect of the prevailing patterns of university governance in Africa, nay elsewhere.

In addition to being illustrative, the typologies considered in Table 2 overlap substantively. Hence, the most reasonable approach to understanding them is to think in terms of a continuum or spectrum. In this regard, one could possibly be talking of the following sub-categories: extreme managerialism/ executivism, moderate managerialism/ executivism, low managerialism/ executivism, etc. Notice, however, that the collegial model in the table has no illustrative example. This is deliberate but indicative of the fact that that tradition has become almost crowded out by the contemporary pressures of statism, manegerialism and commercialism.

\section{Collegialism: an analytical framework}

The paper adopts collegialism as an analytical framework. Collegialism in this context presupposes that the university faculty, and staff platforms allied to it, constitute critical centres of decision-making. It refers to a pattern of organizational culture characterized by collegial relations, peer academic leadership, and academic sovereignty. The collegial precept arose in contradistinction to the rising bureaucratization of the university system in the West, following the advent of the welfarist state (Babalola 2014). Concerning the emergence of the model, Sigh (2005: 11) notes that "the traditional emphasis on bureaucracy is being challenged by normative preference for collegiality".

Collegiality is a lateral-cum-horizontal system of collaborative leadership based on the principles of peer consultation, collaboration and participation (Sigh 2005; Mooney, Burns and Chadwick 2012). It emphasizes the leading-from-the-middle approach (Jowi, 2018), whereby faculty members become veritable stakeholders of the university leadership process. Sigh (2005: 11) notes that it is marked by shared leadership, decision- 
making, vision and values. According to Lesniaski, Mcpherson, Fister and Mckinzie (2001: 234), the collegial model is characterized by the following features:

- shared leadership responsibility and governance;

- fluid and non-hierarchical management structure and line of reporting (lateral devolution);

- emphasis on peer relations and consultation rather than on authority and structure.

Applied to the purpose of the paper, it is instructive to note that the university faculty, and staff platforms allied to it, presents the veritable institutional avenues for collegial consultation as they relate to the question of university governance. The emasculation of such avenues through bureaucratic executivism is, therefore, antithetical to the imperative of institutional autonomy as well as academic freedom (Rabah 2015). It is in the light of this fact that the paper posits that such bureaucratization of the university system tends to erode the culture of collegiality, thereby impeding the prospects of university autonomy and academic freedom.

\section{Context, scope, and methodology}

The paper considers its subject matter within the ambit of the governance situations in Nigeria's nascent federal universities. By nascent federal universities is meant twelve newly established national universities, created between 2011 and 2014 (see Table 3). The reason to focus on this category of institution was informed by the fact that they present a more or less atypical internal governance paradigm vis-a-vis the prevailing traditions in the some of the more established universities. These universities share some striking semblances which hold critical implications for the study. First, they emerged in the era where public universities in Nigeria are at the peak of crises of institutional autonomy and academic freedom. Secondly, they got their administrators principally from the established universities where the ethos of institutional autonomy and academic liberty have been substantially compromised and overly vitiated.

Thirdly, and more importantly, these institutions took off with a good chunk of earlycareer and novitiate academics most of whom would have to work for several years to earn their full academic tenure. An academic taking up a first appointment in Nigerian university system is required by law to serve a mandatory probationary period of three years before his appointment is 'confirmed' and therefore 'tenured'. Within this probationary period, such a staff is merely holding a provisional appointment which could be terminated at any point by the management under various pretexts that may not necessarily agree with due statutory procedures. The dominance of this category of academics in the new universities creates a dicey asymmetry between the management and the faculty, with the former retaining the powers to 'summarily' dismiss any academic 
staff that is considered a threat to its 'authority'. This is more so apparent given the sheer absence of check-mating academic staff union platforms in those universities in their early years of nascence. The above scenario festered in a peculiar institutional context where the pioneer vice-chancellors $a b$ initio operated as paramount bureaucrats amidst an overly ad-hoc establishmentarian set-up bereft of properly constituted Councils and the Senates (Okoli 2016).

Table 3. Newly Established Federal Universities in Nigeria, 2011-2014

\begin{tabular}{|l|l|l|}
\hline University & State of Domiciliation & Year of Establishment \\
\hline Federal University Lafia & Nasarawa & 2011 \\
\hline Federal University, Dutse-Ma & Katsina & 2011 \\
\hline Federal University, Dutse & Jigawa & 2011 \\
\hline Federal University, Lokoja & Kogi & 2011 \\
\hline Federal University, Otu-Oke & Bayelsa & 2011 \\
\hline Federal University, Oye-Ekiti & Ekiti & 2011 \\
\hline Federal University, Wukari & Taraba & 2011 \\
\hline Federal University, Ndufu-Alike & Ebonyi & 2011 \\
\hline Federal University, Kashare & Gombe & 2011 \\
\hline Federal University Birnin-Kebbi & Kebbi & 2014 \\
\hline Federal University, Gashua & Yobe & 2014 \\
\hline Federal University, Gusau & Zamfara & \\
\hline
\end{tabular}

Source: Authors' compilation.

Note: the above names and locations are as documented in the enabling Statutes establishing the universities; they do not necessarily represent the current reality in all cases. For instance, Federal University, Ndufu Alike has been renamed Alex Ekwueme University, Ndufu-Alike.

The paper focuses on the internal structures of leadership and decision-making in one of such new universities with emphasis on how the workings of bureaucratic executivism in its system tend to negate collegiality, and by extension university autonomy and academic freedom. For ethical-cum-strategic reasons, the identity of the focal university along with those of the study's participants have been anonymized. The study approaches the internal dimension of the university governance problematique from the standpoint of the eroding impact of bureaucratic executivism on faculty-level collegiality. Although the paper focuses on a particular university set-up, its conception was simulated against the 
backdrop of corroborated experiences in other federal universities in Nigeria, especially those that were in their nascent years of operation. Hence, the outcome could reasonably apply, mutatis mutandis, to some of these universities.

The paper is a descriptive-analytical case study based on a combination of primary and secondary sources of data. Primary data were sourced from personal observations as well as shared lived experiences of select mid-career academics in the focal institution elicited through corroborated study-chats (strategically informalized purposive conversations). Altogether, nineteen participants with the average service year of three years in the focal institution were interfaced with in the course of the underlying study, in addition to the co-authors. Proceeds of such study-interactions (herein reported variously as personal observation or personal communication) were synthesized into the corpus of data elicited via personal observations and shared lived experiences. Secondary data were derived from documentary resources, such as statutory instruments, reports, memoirs, and relevant scholarly literature. The thrust of analysis is qualitatively prosecuted in themes, drawing selectively from relevant desk and field sources. There is a modest attempt to ground the analysis on the theory of collegialism. Analytical triangulation is applied in order to synthesize insights from the various data sources.

The origin and substance of the paper owe a lot to the proceedings of the 2019 Higher Education Policy Initiative (HEPI) Institute, held in University of Ghana, Legon, from 20th to 30th May, 2019, wherein the lead author participated as a laureate. The various presentations by resource-persons/ facilitators and co-laureates as well as the side-line activities, such as sessional discussions/ conversations, research-writingpublishing clinics, and group engagements, formed the veritable platforms that shaped the study and determined its outcome presented herein. The lead author has been a tenured mid-career academic and formerly a former programme coordinator as well union leader in a one of the newly established public universities in Nigeria. The co-author is a colleague and associate in such an institution. Both authors had put in 8 years of continuous tenure prior to the conduct of the study that yielded this paper. The authors' positionality as mid-career faculties and peers is expected to leverage shared lived experiences in such a manner that profits the analysis. In appropriating of the authors lived experiences and personal observations, conscious effort was made to eschew personal prejudices in order to reasonably stay within the bounds of analytical objectivity and systematization. To this end, the authors simulated ab initio the study through solicited peer-discussions whereby select faculty colleagues across academicadministrative divides within the focal university volunteered them valuable insights that mediated their personal biases. Additionally, the outcome of the study was again subjected to another round of detached scrutiny by select members of same peer-group in order to further moderate manifest author prejudices. 


\section{Bureaucratic executivism and the collegial debacle: an empirical narrative on the focal university}

So far in this paper, our discussion on how bureaucracy affects collegiality has bordered largely on theoretical, if hypothetical, generics. This section attempts to reduce the discussion to some concrete specifics by way of empirical illustration and validation. To begin with, it is pertinent to observe that the university that constitutes the locus of analysis herewith apparently represents an extreme case of bureaucratic executivism as well as collegial downturn. This case may not necessarily typify the situation across the public universities in Nigeria. Even the federal universities in the same category as the one under review have their diverse significant peculiarities and specificities. Hence, any attempt to extrapolate or generalize the observations and findings arising from our illustrative case must take into due cognizance its contextual peculiarity as earlier highlighted in the contextual background.

For the avoidance of doubt, the focal university is neither a fictional nor a hypothetical case, although it has been anonymized herewith for ethical reasons. It belongs to the latest generation of federal (national) universities in Nigeria. Established in 2011, the university took off on a miniature campus model with an administrative structure that was overly centralized and top-bloated. Upon inception, the university was inappropriately constituted at the faculty with preponderance of junior and inexperienced academics, some of whom were abusively elevated to important positions as programme coordinators and academic advisers (Okoli 2016). The asymmetry of management-faculty relations in the university has been disproportionately skewed in favour of the management. This has bred an awkward organizational culture that that thrives on subjective-authoritarian rather than on objective-collegial relations. It has also promoted an absurd tradition of organizational behavior among academics that leverages bureaucratic-executivist centralism and conformism. It is upon select indicators of such a peculiar organizational context (see Table 4) that our analysis is predicated.

Table 4. Some Empirical Indicators of Bureaucratic Executivism in the Focal University

\begin{tabular}{|l|l|}
\hline Indicator & Instance(s) \\
\hline Emasculation and usurpation of faculty & $\begin{array}{l}\text { Unilateral appointment of deans by the VC; top-centric } \\
\text { students admission and staff recruitment }\end{array}$ \\
\hline Over-clericalization of academia & $\begin{array}{l}\text { Lecturers' involvement petty clericals; use of lecturers } \\
\text { as laboratory or class attendants }\end{array}$ \\
\hline Establishmentarianist patronage /cronyism & Nepotistic appointment, placement, promotion, etc. \\
\hline Excessive regulation and control & $\begin{array}{l}\text { Signing of daily attendance; oath of secrecy; lecture } \\
\text { notes rule, formulaic teaching }\end{array}$ \\
\hline
\end{tabular}




\begin{tabular}{|l|l|}
\hline Executive authoritarianism & $\begin{array}{l}\text { VC's power is supreme, tending to autocracy; he is an } \\
\text { overlord operating with utmost arbitrariness }\end{array}$ \\
\hline Management-Union tension & $\begin{array}{l}\text { Perceived union's resistance and backlashes resulting } \\
\text { in isolated structural victimization of unionists and } \\
\text { radical scholars }\end{array}$ \\
\hline The VC's boys phenomenon & $\begin{array}{l}\text { Abusive and sycophantic cohorts of cronies who serve } \\
\text { the vested interests of the Vice Chancellor instead of } \\
\text { the collegial ends of the faculty and academia; they } \\
\text { thrive on traded patronage and bureaucratic gossip }\end{array}$ \\
\hline
\end{tabular}

Source: Authors' compilation.

Suffice it to note that some of the attributes observed of the focal university also apply to the rest of them in the same generation, and even beyond. Comparative empirical narratives and anecdotes, however, tend to indicate a more significantly dire situation in the newly established universities. What then are the significance of these awkward contextual and operational scenario? This analytical poser forms the concern of the subsections that follow.

\subsection{Over-clericalization of academia}

The professional mandate of a university academic can be compartmentalized into teaching, research and community service (Okorosaye-Orubite, Paully and Abraham 2012). For such an academic to fare well in those responsibilities, he has to devote the bulk of his career time to intellectual resourcing and less to extra-scholarly engagements. But in the focal university, academics have been made to routinely undertake petty clerical tasks such as registration of students, laboratory and class attendance, and the like. An absurd situation in this respect occurred in 2015/2016 academic session when members of academic staff was required by the management to sign for the collection and submission of classroom keys at a security desk as part of their teaching schedule (Personal communication 2016).

By signing for the keys, a lecturer undertakes to assume responsibility for the safety and security of the facilities in his class within the period of lecture. This arcane practice was encouraged in an institution whose staff distribution is overly skewed in favour of the clerical personnel, with an outright surplusage of such category of personnel amounting to the average ratio of 2:1 (Personal communication 2014). One therefore wonders about the rationale for the involvement of academic staff in such a lowly clerical line of duty.

The involvement of teaching staff in some administrative duties is not altogether condemnable. As a matter of need, faculties require some measure of knowledge of administrative operations in order to consummate their expertise in academic leadership. 
The worry here, however, is the tendency to excessive use of academic rank and file for petty administrative works; especially those that derail far from their original and statutory and professional schedule of duty (cf. Okoli, 2016). Again, the disproportionate amount of time those members of academic staff spend on such 'extraneous' duties has called to question the rationality of the practice in a university setup. It smacks of professional impropriety to reduce an academic staff to the status of ad-hoc clerical personnel, whatever the bureaucratic exigencies are.

\subsection{Excessive regulation and control}

The university is widely acknowledged to be one of the most liberal organizations in the world. In fact, it is often and rightly acclaimed to be the quintessence of that (Babalola 2014; Rabah 2015). However, in the focal institution, there has been much structural restrictions and control. In its early years, the university operated a peculiar mini-campus system that was excessively regimented and regulated (Personal communication 2014). Then, faculties were meant to scan their official identity card at the heavily policed security gate by the main entrance in order to document and confirm their entry and exit (Authors' Personal observation 2014). This practice was justified by the management as a rational contingency policy dictated by what was then considered a volatile security situation in the state where the university was situated. Curiously, whilst this 'securitized bureaucratic regimen' lasted, lecturers running for classes were often denied access into the campus for failure to nominally present their misplaced identity cards (Personal observation 2014).

Lecturers were also required to sign an attendance registrar at the department to document their arrival and departure on daily basis. In a number of isolated cases, such attendance records were used to witch-hunt academics under the pretext of a sinister punctuality rule (Personal communication 2014). Besides the punctuality rule, there was equally a lecture-note precept which required lecturers to prepare their lecture modules in both power-point and full-text versions and make same available to students in soft and hard copies. In addition, lecturers were mandated to engage in 'smart teaching' with the aid of power-point slides (Authors' Personal observation 2014). This pedagogic pattern, to a significant extent, reduced teaching and learning to mechanistic formula bereft of rigour and dynamism. In advancement of this pedagogic modality, the chief executive and cohorts working for him periodically went round the classes to enforce conformity, often interrupting the teaching process.

During 2015/2016 academic session, the management of the university came up with a controversial document whereby members of academic staff were required to sign to an oath of secrecy ostensibly designed to mortgage academic freedom. The accompanying memoir instructed faculties to comply with the 'secrecy directive' or face 
drastic disciplinary sanction. The secrecy document reads inter alia (Official memoir 2016):

I ... do solemnly promise that I will not directly or indirectly reveal, except to a person to whom it is my duty or to whom I am authorized to communicate it, any code work, sketch plan, model, article, note, documents of information entrusted to me by any person holding office in the (university) or the public service of the Federal University of Nigeria, which I may obtain, or to which I have access, owing to my position as a staff of the (university) ... [brackets are authors'].

Incidentally, many were intimidated or cajoled into compliance as they acquiesced and signed the controversial document either under duress or pressure. The effort of the academic staff union to challenge the policy precipitated deep-seated hostility between the management and a segment of the union leadership, snowballing into a showdown on a few of the leaders (Authors' Personal observation 2016). The secrecy policy was very significant because it represented the height of affront to the principle of academic freedom.

\subsection{Emasculation / usurpation of faculty}

The ascendancy of bureaucracy in the focal institution has led to the emasculation of the operational independence and integrity of the faculty. For instance, the authority of the faculty to initiate and lead the process of academic staff recruitment as well as students' admission has been substantially eroded (Personal communication, 2019); see also Ernst 2009; Nwisaka 2014). Same is true regarding other aspects of academic policy and programming. For instance, up to the $2014 / 2015$ academic session, the administration of semester examination was anomalously bureaucratized. In this regard, a faculty required each lecturer to generate as much as 25-50 questions (depending on the scope of the course module) and submit same to the dean, who in turn would hand them in at the office of the Vice Chancellor (VC) for typesetting and reproduction. Here, junior members of non-teaching staff, who were serving as personal aides of the VC, took charge of the process with little or no oversight by a dean. This arcane situation resulted in a major examination leakage scandal in which the office of the VC was indicted by the university's central Examination Misconduct Committee (Authors' Personal observation 2015).

In such an anomalous system, unfortunately, the position of the dean has remained appointive rather than elective, even in sharp contradiction to the provisions of extant statutory guidelines (Staff Handbook, Establishment Act, etc), which clearly stipulates that deans should be elected by a validly constituted Faculty Board. With an appointed dean unilaterally selected by the absolutist Vice Chancellor, the faculty becomes a mere appendage of the VC's office and the management - a management that was poised to elicit 
strict and "slavish adherence to the rules" (McLean and McMillan 2003: 55). This scenario has undermined the capacity of the faculty to oversight the management as well as defend its academic corps from unwarranted executive authoritarianism. More significantly, it negates the ideals of collegiality as well as academic tenure and sovereignty at the faculty.

\subsection{Executive authoritarianism}

The powers of the chief executive in the focal institution are so immense and paramount. The Vice Chancellor personifies an overlord whose dictates are more dreaded than respected (Okoli 2016). With most arbitrary powers to 'hire and fire', the VC is feared as the sole and ultimate determinant of career and tenure prospects. There have been cases of irregular appointments as well as termination of appointment by the management at the instance of the VC (Personal communication 2019). Academics have been summoned, queried, or even penalized for holding critical views, especially those considered to be critical of the university administration. There have also been cases of gross mistreatment of academics by the university authority under disturbing circumstances.

In 2014, a lecturer was chastised and humiliated for trying to enforce discipline during an examination that he invigilated. He had stirred a rush at the close of the examination by threatening students to 'hand in their papers or risk being penalized' (Authors' Personal observation 2014). Amid the rush, a female student sustained an injury. This caused a commotion, attracting the attention of the VC who was on a routine supervision around the arena. Rather than appreciating the objective circumstances of the incident, the VC blamed the occurrence squarely on the invigilator and charged him to formally apologize to the student and foot the bill of her medical treatment (Personal observation 2014). This bizarre occurrence signaled the vulnerability of academics in an institution that not only undermines his academic freedom but also negates his personal dignity.

\subsection{Establishmentarianist patronage}

Establishmentarianist patronage refers to the abuse of public office in service of particularistic self-regarding interests that are personal or primordial. This tendency had manifested in the fashion of nepotism and cronyism in the focal university. Nepotistic considerations have often pre-determined and compromised the process of staff employment, placement and promotion. Some academics have been appointed, placed or promoted based on parochial criteria arising from sectionalist, ethnic, religious or clannish considerations. Career advancement and recognition is at best based on fetish recourse to paper-credentialism and nominal ranking rather than on proven intellectual resourcing and productivity (Okoli 2012). By this, the chief executive ensures that his cronies and support agents are mainstreamed into the rank and file of academia. This 
practice has promoted an obnoxious organizational culture where sycophancy and hypocrisy are priced as standard marks of efficiency and loyalty. Nonetheless, what has been reproduced and perpetrated in such a 'spoil system' is systemic inefficiency and mediocrity. The worst genre of this arcane trend is the phenomenon of VC's Boys. The VC's boys are pseudo-academics and activists that capitalize on their abusive affinities with the Vice Chancellor to undermine collegial ideals and relations in the institution. They thrive on traded patronage earned through sycophancy and malingering. Most of the boys hold juicy and strategic portfolios within the university's management, even as underachieving junior colleagues. They enjoy the booties and perquisites of maladministration, including irregular placement and promotion, as well as unmeritorious recognition.

\subsection{Management-Union tension and antipathy}

One of the critical manifestations of the abusive system under review is managementunion tension and attendant industrial contestations. The endeavours of the academic staff union towards resisting or changing the status quo have often engendered backlashes whose outcomes threatened harmonious industrial relations. For obvious reasons, the management has often sought to subvert the strength of the union by targeting its leaders for disguised persecution under diverse pretexts (Authors' personal observation, 2019). A system of structural inducement and victimization is put in place to condition radically inclined scholars into acquiescence. The consequence of this is a dialectical institutional ambience where enduring stability cannot be guaranteed. The implications of this for institutional progress and sustainability (cf. Okoli 2016) are diversely ominous.

\section{Of bureau-varsity: implications for institutional autonomy and academic freedom}

An ideal university [although one is hardly found nowadays, anyway] is a collegial entity. In this system, leadership is a shared responsibility that is performed at the different committee levels right from the Senate (Central Academic Board) to the various faculty and departmental boards. Leadership in this context is based on academic tenure and expertise, peer consultation, shared governance and collegial democracy (Taiwo 2011; Babalola 2014). Decision-making flows laterally from the faculty and allied academic platforms to the management in a systematically devolved bottom-up pattern. This is not with any prejudice to the prerogative of the management in matters peculiar to establishment. Bureaucratization of the university in the fashion highlighted in the preceding sub-sections stifles the collegial tradition of the university. More significantly, it vitiates the tenets of institutional autonomy and academic freedom. 
To reiterate and amplify what has been said earlier in this paper, institutional autonomy relates to the relationship between the university and its diverse stakeholders with reference to relative but functional operational 'dependence' of the university administration or its faculties (Osisioma 2012; Mukoro 2013; Abdullaheem and Muhammed 2014). It is a matter of leveraging the powers and responsibilities of the university or the faculty thereof in order to bolster their operational efficiency and integrity. There are two dimensions to institutional autonomy, namely external and internal/local (Martin 2016). External autonomy refers to the relationship between the university and the wider society, including the state, industry, and donor agencies. Internal autonomy has to do with the relationship between the university authority and (management/administration) and the faculty. It is concerned with the functional operational autonomy and self-determination of the faculty, especially with regard to academic policies of the university. The conception of institutional autonomy in this study refers discreetly to its internal dimension.

What then does the 'bureau-varsity' tradition presented in this paper portend for institutional autonomy and academic freedom? Essentially, it reduces the faculty to a mere appendage of the management by usurping its statutory mandate. Consequently, critical decisions regarding recruitment, tenure, promotion, discipline, curriculum, and welfare, are made at the managerial level without recourse to the faculty. Rather than being a centre of excellence in terms of collegial relations and academic leadership, the faculty becomes a space for establishmentarianist politics and patronage. In this context, leadership roles are negotiated and assumed through sycophancy rather than meritocracy. This creates an abusive organizational culture that celebrates mediocrity over excellence. With regard to academic freedom, there is much to be desired. The faculty has little or no control over the structure and contents of the curriculum. There prevails a strict epistemic and pedagogic censorship regarding what is to be taught and how teaching is to be delivered. This holds adverse implications for academic freedom and excellence.

It should be pointed out that bureaucratic executivism in the context of university governance is not wholly negative and this study is not entirely averse to it. But overbureaucratization of the university in the measure x-rayed above is tantamount to emasculation of free scholarship. This is antithetical to the original calling of the university. It also negates one of the most cardinal organizing principles of modern democratic society - the principle of liberal thought. This is instructive considering the avowed status of the university as a prime agent of modern civilization and societal transformation. Alas, while the wider society is making incremental progress towards democratization, some Nigerian universities appear to be relapsing into the morass of liberal retrogressions as essentialized by misplaced bureaucratization. 


\section{Conclusion and recommendations}

The university is a prime quintessence of civilization. It is a community where the best and finest of human ideals are espoused. It is also the centre of excellence in terms of human practices and principles. Two of the most acclaimed and cherished principles of the university community are collegialism and liberalism. The former relates to the belief in peer academic leadership while the latter has to do with academic freedom as well as tolerance of alternative viewpoints. These are operational principles in an ideal university where the faculty and academia hold veritable stake in the institutional decision-making. The institutional dynamics in the contemporary university system in Nigeria, however, tends to have made the realization of these values at best problematic. The growing bureaucratic-executivist tendencies in the university administration have occasioned a tradition of management-faculty relations that negate the culture of collegiality, thereby undermining institutional autonomy and academic freedom. It is in the light of this understanding that the paper has examined the collegial debacle in a Nigeria's nascent federal university.

From the illustrative standpoint of what depicts a vintage case, the paper observed that there have been sustained downturn in the collegial ethos of the university in such a manner that undermines the faculty in that context. The paper identifies indicators of these tendencies to include usurpation of faculty's powers by the management, clericalization of academic staff, establishmentarianist patronage, executive authoritarianism, excessive regulation and control, and management-union tension. The implication of this is that bureaucratic imperative of management are overriding collegial concerns at the faculty. So, as the university aggrandizes in bureaucratic essence and excesses, the culture of collegiality gives way to a hierarchical institutional order where internal autonomy and academic freedom virtually turn endangered practices.

To reverse this awkward trend, there is a need for an institutional reform aimed at devolving strategically the system and procedures of university governance in a manner that restores the functional autonomy of the faculty alongside the sovereignty of its academia. To be meaningful and sustainable, such a reform must prioritize the revitalization of faculty-based collegial structures such as the faculty and departmental board, the peer committees, and relevant staff associational fora. The strength and vitality of the faculty as the nucleus of academic decision-making in a university should be restored through strategic measures such as election of deans and heads of departments, peer-mediated promotion and recognition, as well as strict adherence to the statutory provisions that govern official staff-management relations, especially in respect of discipline and welfare. The entrenchment of the aforementioned collegial principles and procedures must be balanced with requisite corporate governance practices in order to make the university globally competitive and progressive. Such practices would include, among others, a moderated corporatist outlooks on scholarship and leadership capable 
of driving academic-cum-managerial excellence without vitiating the prospects of collegialized and autonomized intelectualizing.

\section{Acknowledgements}

The lead author gladly appreciates CODESRIA and its team of staff for funding his participation in the 2019 Higher Education Policy Initiative (HEPI) Institute at Accra, Ghana. The origin and substance of this paper owes a lot to the Institute. Similarly acknowledged are the esteemed team of mentors and resource-persons that made the Institute worthwhile: Ms. Dominique Tania Sambou-Tchicaya and Professors Godwin R. Murunga, Ibrahim Oanda Ogachi, Mahama Duwiejua, Ishmael I. Munene, and Oliver J. J. Seale. The co-laureates are equally fondly acknowledged for their peer-mentoring that has subsisted.

\section{References}

Abdullaheem, I. and Muhammed, A. 2014. "Corporate Governance in Nigerian Higher Education: Issues and Challenges." European Journal of Business and Management 6 (2): 221-228.

Arikewuyo, M.O. 2013. "The Challenge of Academic Freedom in the Nigerian University System." Makarere Journal of Higher Education 4 (2): 247-259. https://doi.org/10.4314/majohe.v4i2.9

Aspromourgos, T. 2012. "The Managerialist University: An Economic Interpretation." Australian Journal of Universities Review 54 (2): 44-49.

Babalola, A.A. 2014. University Autonomy and Good Governance. Text of a Lecture delivered at the 2014 Conference of the Committee of Pro-Chancellors of Nigerian Universities held at Shehu Musa Yar'adua Center, Abuja, June 10-11, 2014.

Baldgridge, J.V. 1971. Models of University Governance: Bureaucratic, Collegial and Political. Research and Development Memorandum, 77, Stanford University.

Bricks, N. 2013. An Overview of University Education and Administration in Nigeria. Lecture delivered at a 3 Day Retreat organized for Members of the Governing Council of Rivers State University of Science and Technology, Port-Harcourt, 23rd January, 2013.

Deem, R. 2000. 'New Managerialism' and the Management of UK Universities. Research Report, Department of Education Research and the Management School, Lancaster University, ERRC: R000237661.

Ekundayo, E.T. and Adedokun, M.O. 2009. "The Unresolved Issue of University Autonomy and Academic Freedom in Nigerian Universities." Humanity \& Social Sciences 4 (1): 61-76.

Engwall, L. 2007. "The Universities, the State and the Market. Changing Patterns of University Governance." Higher Education and Policy 19: 87-104. https://doi.org/10.1787/hemp-v19-art19-en

Ernst, B. 2009. "The Erosion of the Tenure System and Academic Collective Bargaining in the Academy: An AAUP Perspective." Journal of Collective Bargaining in the Academy 0 (17). [online]. [cit. 20. 7. 2020]. Available at: https://thekeep.eiu.edu/cgi/viewcontent.cgi?article=1185\&context=jcba

Harvey, L. 2016. The New Collegialism: Improvement with Accountability. Paper originally presented at the 16thAnnual EAIR Forum, Amsterdam, 21-24 August.

Jonathan, R. 2006. Academic Freedom, Institutional Autonomy and Public Accountability in Higher Education: A framework for Analysis of the 'State-sector' Relationship. Pretoria: The Council for Higher Education.

Jowi, J.O. 2018. Deans in Kenyan Universities: Their Leadership Styles Impacts on Staff Commitment. Ph.D. Thesis, University of Twente, June 2018. 
Leshie-Hughes, D.H.H. 2013. English Universities: Managerial Movement from Academic Collegial Administration to Corporate Managerialsm. M.A. Dissertation, Hertfordshire Business School, University of Hertfordshire.

Lesniaski, D., McPherson, K.H., Fister, B. and McKinzie, S. 2001. “Collegial Leadership in Academic Libraries.” In: ACRL Tenth National Conference Proceedings, pp. 233-239.

Mama, A. 2006. "Towards Academic Freedom for Africa in the 21st Century." JHEA/RESA 4 (3): 1-32.

Marini, G. and Reale, E. n.d. "How does Collegiality survive Managerially led Universities? Evidence from a European Survey." European Journal of Higher Education 6 (2): 111-127. https://doi.org/10.1080/21568235.2015.1070676

Martin, B.R. 2016. “What's happening to our Universities?" Prometheus: Critical Studies in Innovation 34 (1): 7-24. https://doi.org/10.1080/08109028.2016.1222123

McLean, I. and McMillan, A. 2003. Concise Oxford Dictionary of Politics. Oxford: Oxford University Press.

Mignot-Gerard, S. 2003. 'Leadership' and 'governance' in the Analysis of University Organizations: Two Concepts in Need of Deconstruction." Higher Education Management Policy 15 (1): 135-164. https://doi.org/10.1787/hemp-v15-art18-en

Mooney, D., Burns, D. and Chadwick, S. 2012. "Collegial Leadership: Deepening Collaborative Processes to Advance Mission and Outcome." In: A Collection of Papers on Self-study and Institutional Improvement. High Learning Commission.

Mukoro, A.S. 2013. "The Erosion of University Freedom and Autonomy: Nigerian Experience." Journal of Education and Social Research 3 (6): 129-137. https://doi.org/10.5901/jesr.2013.v3n6p129

Murphy, M. 2008. Finding the Fault-line of Accountability: Higher Education, Bureaucracy and Academic Identity. Paper presented at the British Educational Research Association's Annual Conference, HariotWatt University, Edinburgh, 3-6 September, 2008.

Nwasaka, K.O. 2014. Bureaucracy and Decision-making in Public Universities in Uganda: A Comparative Survey. Ph.D. thesis, Mbarara University of Science and Technology, Uganda.

Nybom, T. 2008. University Autonomy: A Matter of Political Rhetoric? Portland Press.

Ogbogu, C.O. 2013. "The Role of Committees in the Decision-making Process in Nigerian Universities." International Journal of Business and Management 8 (16): 72-77. https://doi.org/10.5539/ijbm.v8n16p72

Ogunbadeniyi, O. and Uhunmwuangho, S.O. 2014. "Strategies for Effective Governance in Nigeria: University of Benin in Focus." AFRREV-IJAH: An International Journal of Arts and Humanities 3 (4): 157-175. https://doi.org/10.4314/ijah.v3i4.12

Okoli, A.C. 2012. "Credentialism and Bastardisation of Academic Publishing in Nigeria: A Comment." Journal of Development Studies 1 (1): 93-98.

Okoli, A.C. 2016. "Leadership and Institution-building in Federal University Lafia, 2011-2015." FULafia Journal of Social Sciences 1 (1): 51-62.

Okorosaye, O., Paulley, G.F. and Abraham, N.M. 2012. "University Autonomy, Academic Freedom and Academic Staff Union of Universities (ASUU) Struggles in Nigeria: A Historical Perspective." Asian Social Science 8 (12): 265-275. https://doi.org/10.5539/ass.v8n12p265

Olorunsola, E.0. 2018. "Erosion of Autonomy: The Pitfall of Educational Management in Nigerian Universities." International Journal of Educational Administration and Policy Studies 10 (4): 33-38. https://doi.org/10.5897/IJEAPS2017.0521

Ordorika, I. 2013. "The limits of University Autonomy: Power and Politics at the Univeridad Nacional Autonoma de Mexico." Higher Education 46: 361-388. https://doi.org/10.1023/A:1025382504110

Osisioma B.C. 2012. Governance in Nigeria Universities: The Position of the University Internal Auditor. Paper presented at National Conference of Committee of Heads of Internal Audit Departments in Nigerian Universities, Federal University of Technology, Owerri, November 5, 2012. 
Pollitt, C. 2014. Manegerialism redux? Keynote Address to the 2014 Eiasm Conference, Edinburgh, 24th August 2014.

Rabah, I. 2015. "Introduction of the Collegial Model: Erosion of the Collegial Model, shared Governance and Academic Tenure." Global Journal of Management and Business Research 15 (2): 25-36.

Russell, C. 1993. Academic Freedom. London: Routledge.

Sigh, P. 2005. "Use of the Collegial Leadership Model of Emancipation to Transform Traditional Management Practices in Secondary Schools." South African Journal of Education 25 (1): 11-18.

Taiwo, E.A. 2011. "Regulatory bodies. Academic Freedom and Institutional Autonomy: Issues and Challenges -the Nigerian Experience." JHEA/RESA 9 (1-2): 63-89.

Weinberg, A.M. and Graham-Smith, G. 2012. "Collegiality: Can it survive the Corporate University?" Social Dynamics 38 (1): 68-86. https://doi.org/10.1080/02533952.2012.700181 